\title{
青熱脆性を考慮した広い温度域に適用可能な炭素鋼の構成式*
}

\author{
立矢宏*1, 新本哲平*2, 高木幸司*3 \\ 放生明 廣*1, 茶谷明 義*1

\section{Temperature Dependent Constitutive Equation for Carbon Steels with Consideration of Blue Brittleness} \\ Hiroshi TACHIYA*4, Teppei ARAMOTO, Kouji TAKAGI, \\ Akihiro HOJO and Akiyoshi CHATANI \\ ${ }^{* 4}$ Department of Mechanical Systems Engineering, Kanazawa University, \\ 2-40-20 Kodatsuno, Kanazawa-shi, Ishikawa, 920-8667 Japan \\ This paper presents a temperature dependent static constitutive equation for carbon steels, which \\ can be applied for wide temperature range involving the range where blue brittleness occurs. \\ Generally, a stress induced in steel at a certain strain decrees with the temperature. However, the \\ occurrence of blue brittleness of steels increases the values of work hardening. As a result, the \\ stresses increase with the temperature due to the blue brittleness. Thus, the stress-strain relation- \\ ships of steels seemingly have negative dependence to the temperature within the range involving the \\ blue brittleness. Since this phenomenon arises remarkably at static strain-rate, the present paper has \\ proposed a temperature dependent static constitutive equation. Concretely, the paper decomposes the \\ stress-strain relation of steels into an unaffected part and affected part by the blue brittleness, and \\ derives equations revealing those parts respectively. The proposed constitutive equation is expressed \\ by the sum of them. The paper actually obtains unknown material constants involved in the proposed \\ equations by a nonlinear least squares from measured results and confirms the appropriateness of the \\ proposed constitutive equation over the wide temperature range.
}

Key Words : Constitutive Equation, Temperature Dependence, Blue Brittleness, Elevated Temperature, Carbon Steels, Stress-plastic Strain Curve

\section{1. 諸 言}

材料の変形挙動は，ひずみ速度および温度に依存す ることが多く，一般に変形応力がひずみ速度の上昇に 伴い増加し，温度の上昇に伴い低下する。これら材料の 弾塑性変形挙動を構成式として表すことは, 材料その ものだけでなく, 構造の変形解析や, 塑性加工時の加工 パラメータの決定などのために重要である(1).

そこで,これまでに, 転位の運動力学的考察に基づく 構成式がいくつか考案されている(2) (4). 著者らも, 先 に温度およびひずみ速度依存性を考慮した動的構成式 を提案するとともに, 式中の材料定数の決定方法を示 した(5). また，実際にSS400炭素網を対象として構成式 を決定し, 広いひずみ速度範囲および温度域で, その変 形挙動をよく表すことを確認した(5). しかし, 同構成式 は適用可能な範囲として, 常温から青熱脆性が生じな い温度までを対象とした。

多くの延性金属は, ある温度域で変形能の低下を生 じる(6). 本論文で対象とする炭素鋼においても, 静的な

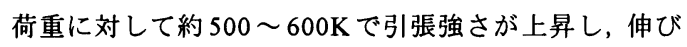
と絞りが低下することが知られており，青熱脆性と呼 ばれている(7). 青熱脆性は, 炭素鋼に含まれる溶質原子

* 原稿受付 2004 年 2 月 20 日.

*1 正員, 金沢大学工学部 ( 3 920-8667 金沢市小立野 2-40-20).

$* 2$ 学生員, 金沢大学大学院自然科学研究科.

*3 金沢大学大学院自然科学研究科.

E-mail : tachiya@t.kanazawa-u.ac.jp
$\mathrm{C}, \mathrm{N}$ が転位を固着し, 粘性抵抗として作用するために 起こるもので，ひずみ時効のひとつであると考えられ ている(8). 青熱脆性の影響は, 変形速度の比較的遅い領 域において顕著に現れ, 変形速度の増加に伴い, その出 現温度域は高温側に移行し，影響が小さくなることが 知られている(7).

上述のように, 炭素鋼の変形応力は, 通常, 温度の上 昇に対して低下寸るが, 青熱脆性が生じた場合, 変形応 力は増加傾向を示す. したがって, 見かけ上は, ある温 度域に達すると，それまでとは逆の温度依存性を示す ことになる.このような影響は, 先に提案した構成式(5) では表すことはできず,また, 他にも青熱脆性を考慮し た構成式はほとんど見あたらない.しかし, 上述のよう に，特に静的なひずみ速度域では青熱脆性による影響 は大きく，高温下における材料および構造の変形現象 の予測および解析を行うためにも，その影響を考虑し た構成式の確立が望まれる.

そこで, 本論文ではSS400およびS45C炭素鋼を対象 とし, 青熱脆性域を含む広い温度下で適用可能である 静的応力 - 塑性ひずみ関係を表す構成式を提案する.

\section{2. 試験方法および結果}

$2 \cdot 1$ 試験方法 はじめに, SS400炭素鋼を試験片 として行った高温下における一軸負荷静的圧縮試験(5) の結果を用いて, その変形挙動の温度依存性を示す. 
高温下における静的圧縮試験(5)には，万能試験機(島 津社製 AG-10TD)を使用した。試験片は, SS400炭素鋼 納入材に，両端面が試験片長手方向に対して直角とな るよう研削仕上げを施した, 長さ $10 \mathrm{~mm}$, 直径 $9 \mathrm{~mm}$ の円 柱とした，その化学組成を表 1 に示す，なお，試験時に は試験片両端に二硫化モリブデンを塗布して摩擦の軽 減をはかるとともに, 圧縮後の試酫片の形状を観察し， 変形がほぼ一様であることを確認した。

試験片に生じる応力值は, 試験機付属のロードセル で測定した. 試験片のひずみは, 試験片にひずみゲージ などを直接貼付できないため, 最小分解能が $0.8 \mu \mathrm{m}$ であ る非接触変位測定器を用い, 上下圧縮台座の変位量を 測定し, 双方の差より算出した.ただし, 試験片長が短 いことから, 弾性域の変形量が小さく, 非接触変位測定 器で試験片の初期の弾性変形分に相当する微小なひず みを测定することは困難であった. そこで, 测定值の記 録対象を降伏点近傍以降とした，なお，降伏点は，万能 試験機による試験片の圧縮が低速で，かつ，ほぼ一定速 度であるとみなし，応力値の時間に対する変化率が急 激に減少する箇所として仮定するとともに，同点近傍 においてひずみに対する応力值の変化も急激に減少す ることを確認して決定した(5).

試験片の温度は，静的圧縮を行う長時間にわたり一 定に保たなければならない.そこで, セラミックファイ バースリーブで絶縁した市販のニクロム線を試験片に 直接巻きつけて加熱し保温した，試験片の温度は熱電 対で測定するとともに, 温度調節器を用いて, ニクロム 線による加熱量を制御し温度を一定に保った。試験片 圧縮部の概略を図 1 に示す.

2.2 試験結果上述の方法により，常温（293K）

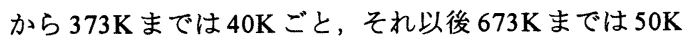
ごとに, 計 9 種類の温度下で試験を行った. なお, 試験 速度は, 試験片に生じる塑性ひずみ速度が $10^{-4} \mathrm{~s}^{-1}$ 程度と なるように調整した．静的試験より得た $293 ， 473 ， 573$ および673KにおけるSS400炭素鋼の静的応力一塑性ひ ずみ関係を図 2 に示す.なお，本論文で対象とするひず みは数\%程度と小さく, 塑性域のみを考慮することか ら，応力およびひずみは公称值を用いることとする.

図 2 より常温と $473 \mathrm{~K}$ の結果を比較すれば, 塑性ひず みに対する応力值が温度とともに減少することがわか る.しかし，573Kにおいて，塑性ひずみに対する応力 值は, $473 \mathrm{~K}$ の結果に比べ顥著な増加傾向を示し, さら に, 673Kの結果では，また，減少することがわかる.こ のような傾向を詳細に検討するため, 図3に塑性ひずみ が3\%である時の静的応力と温度の関係を $\triangle$ で表す. 図 3 より, 常温から温度が上昇するにつれ, 応力值が減少
Table 1 Chemical composition of SS400 (mass\%)

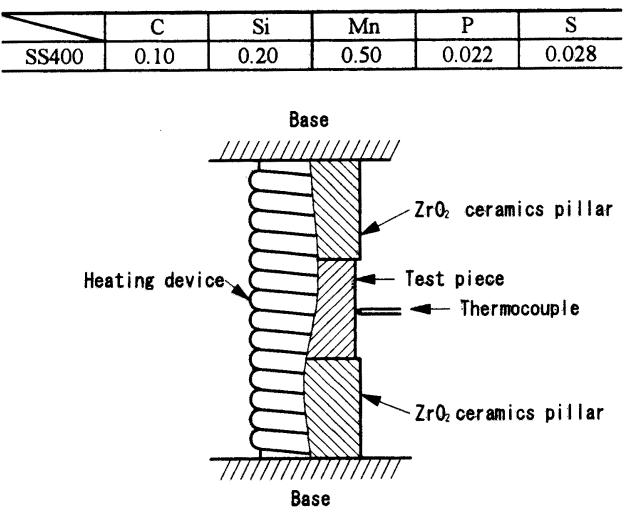

Fig.1 Schematic of the static compression test

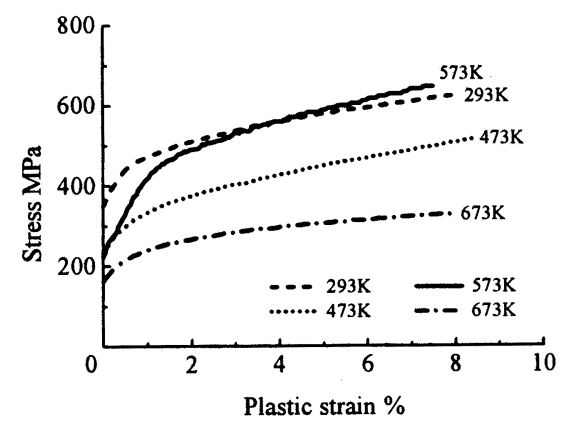

Fig.2 Static stress - plastic strain curves on SS400

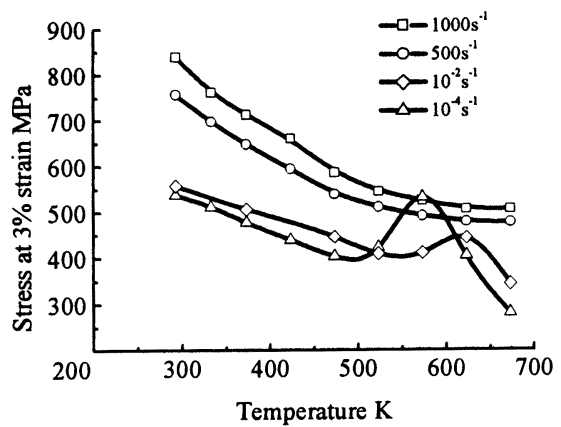

Fig. 3 Relationships between stress and temperature on SS400

することが確認できる，しかし，500K 付近に達すると 応力值が増加して 573 付近で最大となり, それ以降, 再 度減少する. 図2において応力値が温度に対して急激な

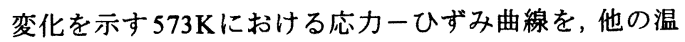
度下における曲線と比較すれば, やや鋸波状を呈して いることがわかる.これらの現象はいずれも, 炭素鋼に 特有な青熱脆性の影響である(7)(8).

さらに, 比較のため図 3 中に, 以上の静的試験で用い た同一試験片による塑性ひずみ速度が約 $10^{-2}, 500$, 
$1000 \mathrm{~s}^{-1}$ における一軸負荷圧縮試験の結果を, それぞれ $\diamond, \bigcirc, \square て ゙$ 示す. 塑性ひずみ速度が約 $10^{-2} \mathrm{~s}^{-1}$ での結果 は, 上述の万能試験機を用いて得た。塑性ひずみ速度が 約 $500,1000 \mathrm{~s}^{-1}$ の結果は, ホプキンソン棒形一軸衝擊圧 縮試験（HPB試験）より得た。なお, HPB 試験では, あ らかじめ小型炬で加熱した試験片を試験機に迅速に設 置することにより，高温下での圧縮試験を行った(5).

同図より，塑性ひずみ速度 $10^{-2} \mathrm{~s}^{-1}$ の結果では，623K 付近で静的な場合と同様に応力値が增加している。 た だし, 増加の程度は静的な場合に比べれば緩やかであ る.また, 塑性ひずみ速度 $500,1000 \mathrm{~s}^{-1} に お け る$ 㐫力と 温度の関係においては, 急激な応力值の変化はみられ ないが, 温度に対する応力值の減少が緩やかになるこ とがわかる。

上述の結果は, 変形速度の上昇に伴い転位を固着す る溶質原子の拡散速度の上昇が必要となるため, 青熱 脆性の現れる温度域が高温側に移行する現象(7)(8)をよく 表している.また，高温になるほど応力に対する温度の 影響が強くなるため青熱脆性の影響は小さくなる(7)(8).

以上より，青熱脆性域において炭素鋼の塑性変形挙 動は, 通常と逆の温度依存性を示し, その影響は, 低ひ ずみ速度下において顕著に表れる.そのため, 特に静的 応力下における青熱脆性を考虑した構成式が重要であ る.そこで本論文では，まず，以上に示した測定結果な どを基に，青熱脆性を考虑した広い温度域を対象とす る静的応力一塑性ひずみ関倸を表す構成式を検討する.

\section{3. 青熱脆性を考虑した構成式}

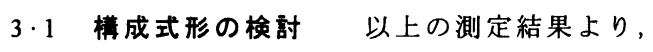
SS400炭素鋼に生じる応力と温度との関係は, 図4(a)に 示す概略図のように，青熱脆性域において加工硬化量 の増加に伴う急激な応力值の上昇を生じる. 本論文で は，このような温度と応力の関係が図 4(b)に示すよう に, 2 つの応力成分 $\sigma_{\mathrm{I}}$ および $\sigma_{\mathrm{n}}$ によって表されると仮 定する.すなわち， $\sigma_{1}$ は青熱脆性の影響を受けず，温 度上昇に対して単調减少し, 通常の温度依存性を示す 成分を， $\sigma_{\mathrm{II}}$ は青熱脆性により増加する応力成分を表 す. 提案する構成式は, これら2つの成分を組合せるこ とにより表すこととする.

まず, 青熱脆性の影響を受けず, 温度上昇に対して単 調减少する応力成分 $\sigma_{1}$ を表す式形について検討する. 金属材料の真応力 $\sigma$ と真ひずみ 表される(9).

$$
\sigma=K \varepsilon^{n}
$$

前報(5)では，式(1)を基本とし，青熱脆性の影響が生じ ない温度域の応力ー塑性ひずみ関係を表す式を提案し た. 本報においても同式を青熱脆性の影響を考慮しな

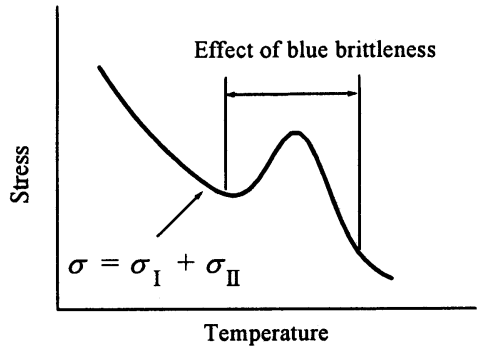

(a) Schematic of the stress-temperature relationship of steels

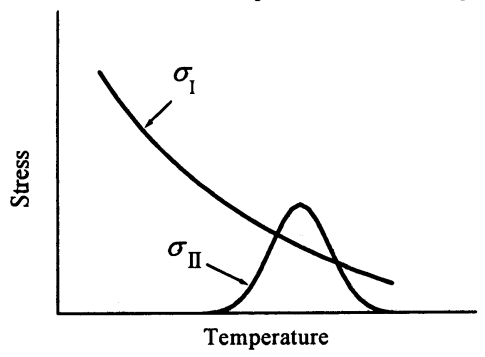

(b) Decomposition of the stress-temperature relationship Fig.4 Relation between the stress and temperature of steels い応力の成分 $\sigma_{I}$ を表す式として用いる. すなわち

$$
\sigma_{\mathrm{I}}=K\left(\varepsilon_{p}+\alpha\right)^{n}
$$

ここで, $K, \alpha, n$ は温度に依存する材料定数であり, $\varepsilon_{p}$ は塑性ひずみを表し， $\alpha$ は降伏ひずみに相当する.式(2) において塑性ひずみ $\varepsilon_{p}$ を零とすれば，各温度下の降伏 応力 $\sigma_{y}$ は次式で表される.

$$
\sigma_{y}=K \alpha^{n}
$$

また, 降伏点近傍において, 弾性域も含めた応力ーひず み曲線の変化率, すなわち, 接線のこう配の変化が連続 であるとすれば縌弾性係数 $E$ が次式で表される.

$$
E=\frac{\sigma_{y}}{\alpha}
$$

次に, 青熱脆性の影響を表す $\sigma_{\mathrm{I}}$ の関数形について検 討する. 図4の概略図に示すように， $\sigma_{\Pi}$ は青熱脆性域 において温度の上昇に伴い急激に増加し, ある温度を 越えると減少する。.また，青熱脆性域以外では，その值 は零となる.物理的な考察から,このような現象を現す 関数形を導くには，青熱脆性の原因となる溶質原子に よる転位の固着などを測定する必要があるが, 実験的 に困難であるため, 本論文では同現象を近似すること を主目的とし, 種々の関数形を検討した. その結果, 温 度に対するこのような変化を表す $\sigma_{\text {II }}$ の関数形として次 式を提案する。

$$
\sigma_{\mathrm{II}}=C_{1} \exp \left[C_{2}\left(T-T_{0}\right)^{2}\right] \varepsilon_{p}^{C_{3}}
$$


$C_{1} \sim C_{3}$ および $T_{0}$ は未知の定数である. 上式の指数関数

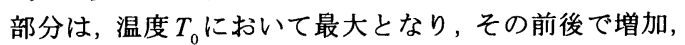
滅少する関数である. $\varepsilon_{p}{ }^{C_{3}}$ は, 塑性ひずみの影響を表す 項として指数関数に乗じたものであり, 図 2 における $573 \mathrm{~K}$ の測定結果が示すように, ひずみの増加とともに 青熱脆性の影響が増加する効果を表すために用いる.

以上の結果より, 本論文で提案する青熱脆性域を含 む温度域で静的応力 $\sigma_{s t}$ と塑性ひずみ $\varepsilon_{p}$ との関倸を表す 構成式の式形を $\sigma_{1}$ と $\sigma_{\mathrm{II}}$ の和として次式で表す.

$$
\sigma_{s t}=K\left(\varepsilon_{p}+\alpha\right)^{n}+C_{1} \exp \left[C_{2}\left(T-T_{0}\right)^{2}\right] \varepsilon_{p}{ }^{C_{3}} \cdots(6)
$$

なお, 実際の変形メカニズムは青熱脆性現象における, ひずみの减少などによると考えられ, 構成式の構築に おいては青熱脆性に関与する塑性ひずみの変化を応力 などの関数として表すことも考えられる.しかし, 本論 文では強度の変化に直接影響する青熱脆性域における 応力の特徵的な現象を, 従来用いられてきた式(1)と同 様に塑性ひずみに対して簡便に表すことを主目的とし て，式(6)を構成式として検討する．また，動的な応力 一ひずみ関係を表す，ひずみ速度依存形動的構成式で は, 静的応力に対する動的応力の増分である過応力を パラメータとする場合が多く, 通常過応力はひずみ速 度とともに増加する(10). しかし, 青熱脆性域で単純に 過応力を求めれば, 図3から予測されるように, その值 はひずみ速度の増加に対し減少し，負となることもあ る.これは, 従来の構成式が青熱脆性による影響を考慮 していないためであるが, 以上で提案した静的構成式 を用いれば青熱脆性の影響を含まない $\sigma_{\mathrm{I}}$ の項を基に過 応力を求め,さらに, ひずみ速度依存性を考慮した青熱 脆性の影響を付加することで, 高ひずみ速度域での応 カ一塑性ひずみ関係を表すことが考えられる．これら に関しては今後の検討課題としたい.

3.2 材料定数の決定法 前報では, 式(3)に含まれ る材料定数 $K, \alpha, n$ がいずれも温度に対して線形に変 化するとして, 常温 (293K) および473Kでの応力一塑 性ひずみ関係の湘定值を近似することにより，これら の值を表す 1 次式を決定した。 その結果, 式(3)は $293 \mathrm{~K}$ から $473 \mathrm{~K}$ における応力一塑性ひずみ関係, 縦弾性係 数, 降伏応力をいずれもよく表すことができた(5). 本論 文においても，まず， $K, \alpha, n$ がいずれも温度に対し て線形に変化するとして $293 \mathrm{~K}$ から 473K, さらに, 青 熱脆性の影響が現れなくなる673Kにおける応力ー塑性 ひずみ関係の測定值を近似し式(3)を決定したところ, 得られた構成式は青熱脆性が生じていない範囲で応力 一塑性ひずみ関係, 降伏応力をよく表すことが確認で きた。しかし，緃弾性係数を精度よく表すことはできな

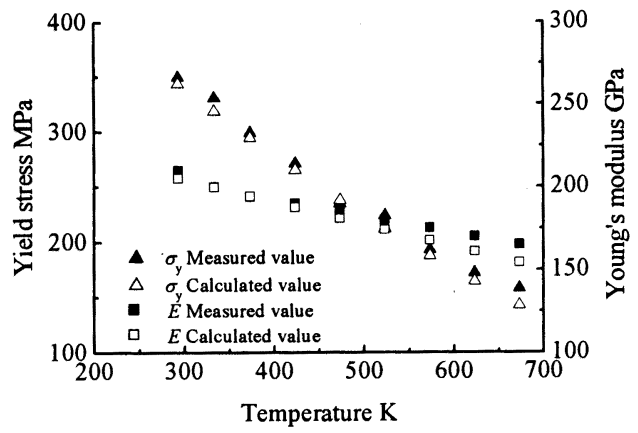

(a)Changes of Yield stress and Young's modulus of SS400 with temperature

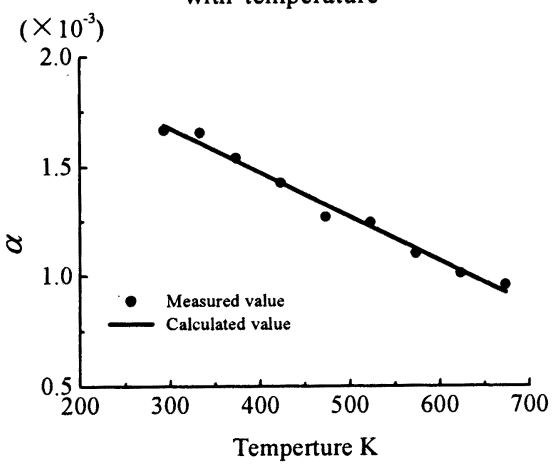

(b) Changes of the yield strain $\alpha$ of SS400 with temperature Fig. 5 Measured and calculated Yield stress, longitudinal elasticity and yield strain of SS400 with temperature

Table 2 Material constants for SS400

(a) $\alpha_{i}(i=0,1)$ of Eq. (7)

\begin{tabular}{c|c}
\hline & Value \\
\hline$\alpha_{0}$ & $2.21 \times 10^{-3}$ \\
\hline$\alpha_{1} \quad\left(\mathrm{~K}^{-1}\right)$ & $-1.89 \times 10^{-6}$ \\
\hline
\end{tabular}

\begin{tabular}{cc|c}
\hline (b) $K_{i}, n_{i}(i=0,1), C_{1} \sim C_{3}, T_{0}$ of Eq. (6), (8) \\
\hline \multicolumn{2}{|c|}{} & Value \\
\hline$K_{0} \quad(\mathrm{MPa})$ & $1.24 \times 10^{3}$ \\
\hline$K_{1} \quad(\mathrm{MPa} / \mathrm{K})$ & -1.05 \\
\hline$n_{0}$ & $1.35 \times 10^{-1}$ \\
\hline$n_{1}$ & $\left(\mathrm{~K}^{-1}\right)$ & $8.02 \times 10^{-5}$ \\
\hline$C_{1}$ & $(\mathrm{MPa})$ & $7.91 \times 10^{2}$ \\
\hline$C_{2}$ & $\left(\mathrm{~K}^{-2}\right)$ & $-4.95 \times 10^{-4}$ \\
\hline$C_{3}$ & & $3.53 \times 10^{-1}$ \\
\hline$T_{0}$ & $(\mathrm{~K})$ & 581 \\
\hline \multicolumn{2}{r|}{}
\end{tabular}

かった.これは, 対象とする温度域が拡大したこと, ま た，降伏点近傍における応力のひずみに対する変化率 が急であり, 応力ー塑性ひずみ関係のみでは, 縦弾性係 数を近似するためのデータが十分でないことが原因と 考えられる.

そこで本論文では，式(7)により応力一塑性ひずみ関 係だけでなく縦弾性係数も表現可能とするために, $\varepsilon_{p}$ を 


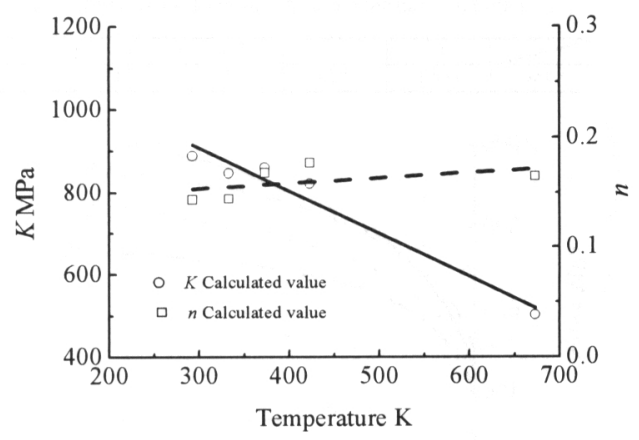

Fig. 6 Changes of $K$ and $n$ of SS400 with temperature

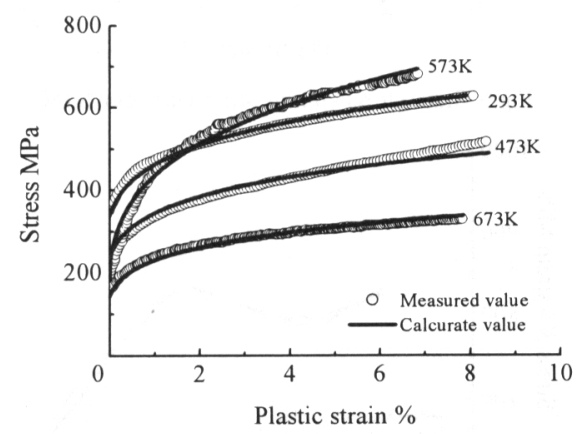

Fig. 7 Measured and calculated stress - plastic strain curves

零として得られる式(6)または式(4)において縦弾性倸 数を表す $\alpha$ の温度に対する変化を, 応力一塑性ひずみ 関係ではなく各温度下における縦弾性倸数および降伏 応力の測定值から直接検討することとした。なお, 本論 文で用いる高温下静的圧縮試験より縦弾性倸数を精度 よく求めることは困難であるため, 前報と同じく同值 がひずみ速度に依存しないとして, HPB 試験の結果よ り求めた ${ }^{(5)}$. 図 5(a)にSS400炭素鋼の温度に対する降伏 応力および緃弾性係数の温度に対する変化をそれぞれ ムおよび西です.ささらに, 同図に示した降伏応力を縦 弾性係数で除して得られる降伏ひずみ $\alpha$ の温度に対す る変化を図5(b)にで示す. 図 5 より, $\alpha$ は温度に対し て，ほぼ線形に変化する，そこで，本論文においても $\alpha$ を温度に対する 1 次式として次式で表すこととする.

$$
\alpha=\alpha_{0}+\alpha_{1} T
$$

上式に含まれる $\alpha_{i}(i=0,1)$ の值を図 5(b)に示した 293， 473，523，573，623，673Kにおける測定結果より決定 して表2(a)に示し, 同值を用いた式(7)より得られる計 算結果を図5(b)中に実線で示す. なお, 测定を行った全 ての温度下の結果を用いても $\alpha_{i}$ はほぼ同じ值となるが, 本論文ではより少数の测定結果より構成式が決定され ることを確認するために以上の温度下での測定結果を 用いた。

次に, 式(6)右辺第 1 項に含まれる未知の材料定数 $K$,

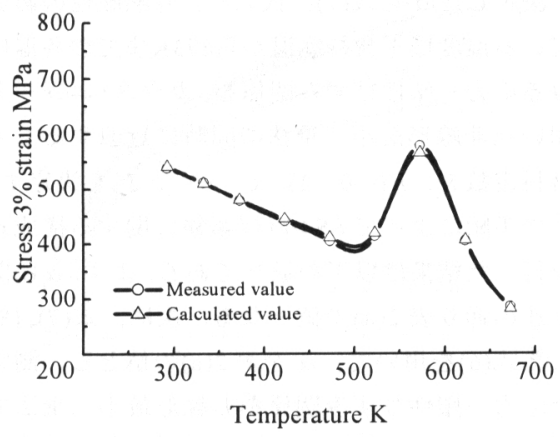

(a) Plastic strain of 3\%

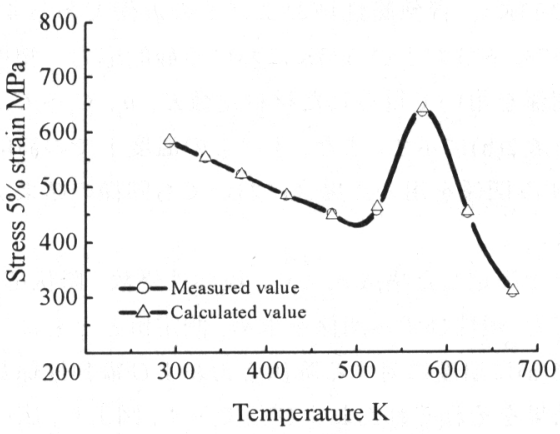

(b) Plastic strain of 5\%

Fig. 8 Relation between stress and temperature on SS400

$n$ の温度に対する変化を検討する. すなわち, 式(7)に 含まれる $\alpha_{i}$ を代入した式(6)の右辺第 1 項を用いて青熱 脆性の影響が現れていない常温(293K)から $423 \mathrm{~K}$, およ

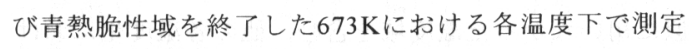
した静的応力ー塑性ひずみ関倸をそれぞれ非線形最小 二乗法で近似して各温度下における $K$ および $n$ の值を 求めた. なお, 非線形最小二乗法にはガウス・ニュート ン法を用いた(11). 得られた結果を図6に示す。青熱脆性 域である $450 〜 650 \mathrm{~K}$ を除くため測定值の間隔に一部幅 があるが, $K$ の值は温度に対してほぼ線形に変化し, ま た， $n$ の值は変化はわずかであるが直線的とみなせる. そこで，前報(5)と同じくこれらを次式で表す.

$$
\left.\begin{array}{l}
K=K_{0}+K_{1} T \\
n=n_{0}+n_{1} T
\end{array}\right\}
$$

以上の結果より, 本論文では青熱脆性を考慮したSS400 炭素鋼の温度依存性構成式を, 式(6)に式(7)および式 (8)を代入した式として提案する。なお，本論文では式 (6)と記した場合, 同式中の $\alpha, K$ および $n$ は式(7)およ び(8)で表されるものとする.

提案する温度依存性構成式に含まれる未知の材料定 数の決定方法は以下の通りである。まず, 式(7)に含ま れる定数 $\alpha_{i}$ は, 先述のように降伏応力を縦弾性係数で 除して得た降伏ひずみを近似することで決定する，さ 
らに，決定した $\alpha_{i}$ を式(7)に代入し，青熱脆性の影響が 生じている温度域を含む室温から673Kまでの各温度下 における応力ー塑性ひずみ関係を, ガウス・ニュートン 法を用いた非線形最小二乗法で同時に近似することで 他の材料定数 $K_{i}, n_{i}(i=0,1), C_{1} \sim C_{3}, T_{0}$ を決定する.

以上の手順によって SS400 炭素鋼に関する構成式の 決定を行った結果は以下の通りである.まず, $\alpha_{i} に$ 関し ては上述の通り表 2(a)の值となる. 次に, 式(7), (8)を 代入した式(6)を用いて， $\alpha_{i}$ を表 2(a)の值とし，測定を 行った応力一塑性ひずみ関係を非線形最小二乗法で同 時に近似し，他の材料定数を決定した．なおここでは 室温(293K), 青熱脆性域およびその近傍である 473,

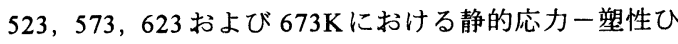
ずみ関倸を用いて得られた材料定数 $K_{i}, n_{i}, C_{1} \sim C_{3}, T_{0}$ の值を表2(b)に示す. また, すべての温度下での静的応 カーひずみ関係を用いた場合においても同様の結果が得 られた。

以上で決定した構成式より, 縦弾性係数, 降伏応力, 静的応力-塑性ひずみ関係を求め, 測定值とともにに示 す. 図5(a)に温度に対する降伏応力および縌弾性係数の

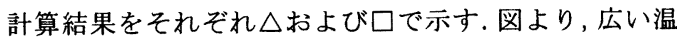
度域で式(6)は実際の縦弾性係数, 降伏応力をよく表し ている. 図7には決定された式(6)より得られる293,

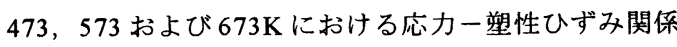
を, 測定值とともに示す. 図7より, 構成式は測定值を よく近似している.なお, 結果は略すが, 測定結果を近 似に用いなかった温度域を含む，他の各温度化におけ る応力一塑性ひずみ関倸も，決定された構成式により よく表すことができた，さらに，塑性ひずみが $3 \%$ お び $5 \%$ での応力值と温度の関係を求め測定值と比較し た.その結果を図 8(a)および(b)に示す. 図 7 および図 8 より, いずれの図においても計算值と測定值が良く一 致しており，提案した式(7)および(5)で表される構成 式が，青熱脆性域を含む広い温度域で試験片に用いた SS400炭素鋼の変形挙動を表し得ることが確認できる.

\section{S45C炭素鋼への適用}

以上で提案した, 青熱脆性を考虑した静的応力一塑 性ひずみ関係を表す構成式が, SS400炭素綱と同様に青 熱脆性を生じるS45C炭素網に対して適用可能であるこ とを確認する. まず, 表 3 に化学組成を示す S45C を供 試材に, $2 \cdot 1$ 節と同一な方法により高温下静的圧縮試験 を行った. 試験片形状はSS400の場合と同一とし, 試験 温度は常温 $(293 \mathrm{~K}), 333 \mathrm{~K}, 423 \mathrm{~K}$, それ以降 $673 \mathrm{~K} ま$

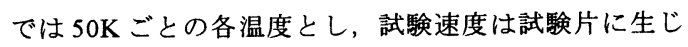
るひずみ速度が約 $10^{-4} \mathrm{~s}^{-1}$ となるように調整した. 静的試 験より得られた静的応力ー塑性ひずみ関係を図 9 に示
Table 3 Chemical composition of S45C (mass\%)

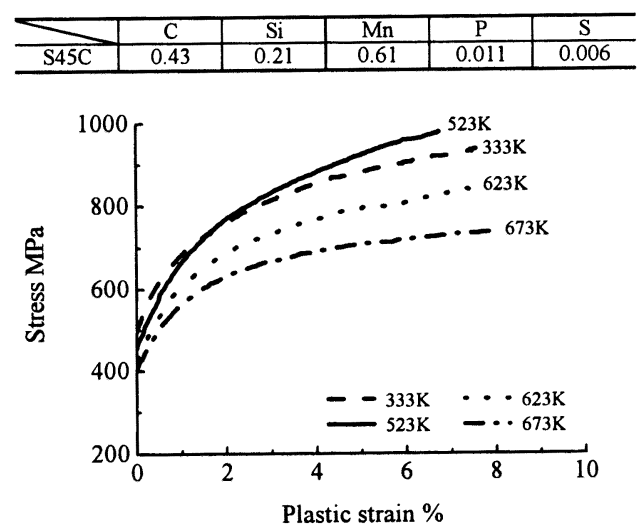

Fig.9 Static stress - plastic strain curves on S45C

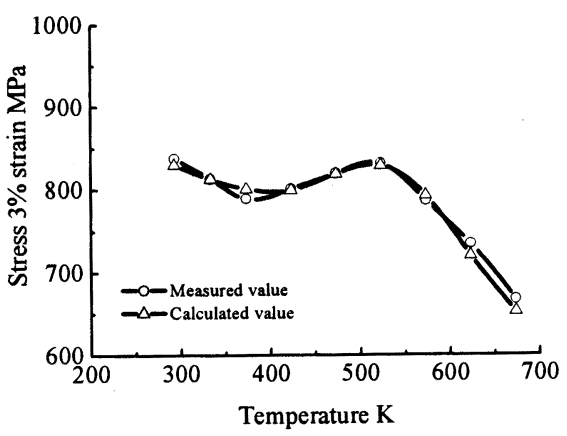

(a) Plastic strain of $3 \%$

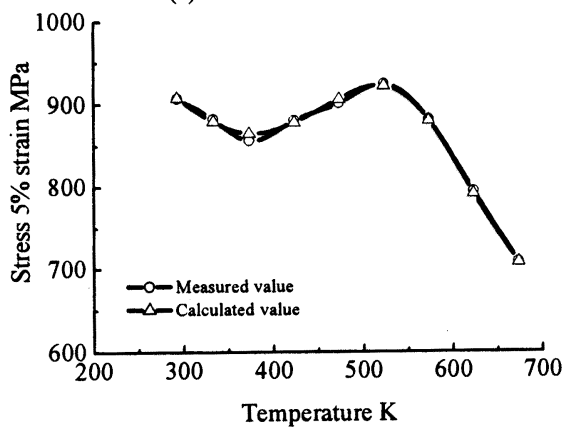

(b) Plastic strain of $5 \%$

Fig. 10 Relation between stress and temperature on S45C

す.さらに，塑性ひずみが $3 \%$ および $5 \%$ における温度

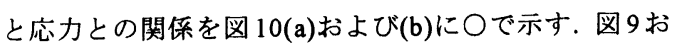
よび図10より，S45C炭素鋼においても応力值が温度と ともに減少する温度依存性が確認される。さらに， $373 \mathrm{~K}$ 付近以降において, 急激な応力值の増加と減少が みられ, SS400炭素網と同様な青熱脆性の影響が確認で きる.

以上の測定結果を用い, 前章で示した方法でS45C炭 素鋼を対象とし, 式(6)に含まれる未知の材料定数を決 


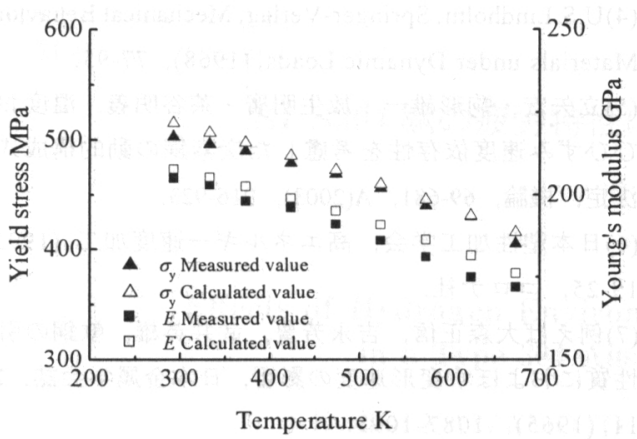

(a) Changes of yield stress and Young's modulus of $445 \mathrm{C}$ with temperature

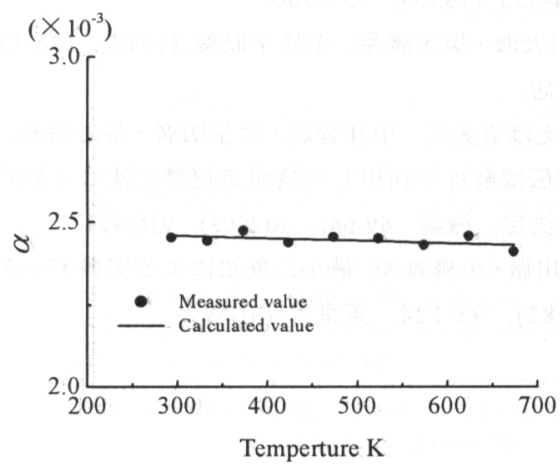

(b) Change of $\alpha$ of $\mathrm{S} 45 \mathrm{C}$ with temperature

Fig.11 Yield stress and Young's modulus

Table.4 Material constants for S45C

(a) $\alpha_{i}(i=0,1)$ of Eq. (7)

\begin{tabular}{|c|c|}
\hline 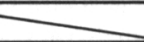 & Value \\
\hline$\alpha_{0}$ & $2.56 \times 10^{-3}$ \\
\hline$\alpha_{1} \quad\left(\mathrm{~K}^{-1}\right)$ & $-2.82 \times 10^{-7}$ \\
\hline
\end{tabular}

(b) (b) $K_{i}, n_{i}(i=0,1), C_{1} \sim C_{3}, T_{0}$ of Eq. (6), (8)

\begin{tabular}{cc|c}
\hline & & Value \\
\hline$K_{0}$ & $(\mathrm{MPa})$ & $1.86 \times 10^{3}$ \\
\hline$K_{1}$ & $(\mathrm{MPa} / \mathrm{K})$ & -1.11 \\
\hline$n_{0}$ & & $1.94 \times 10^{-1}$ \\
\hline$n_{1}$ & $\left(\mathrm{~K}^{-1}\right)$ & $-4.40 \times 10^{-5}$ \\
\hline$C_{1}$ & $(\mathrm{MPa})$ & $6.90 \times 10^{2}$ \\
\hline$C_{2}$ & $\left(\mathrm{~K}^{-2}\right)$ & $-9.88 \times 10^{-5}$ \\
\hline$C_{3}$ & & $5.04 \times 10^{-1}$ \\
\hline$T_{0}$ & $(\mathrm{~K})$ & 537 \\
\hline
\end{tabular}

定する、まず，式(6)中の $\alpha$ を表す式(7)に含まれる未 知の材料定数 $\alpha_{i}$ を決定するために, SS400 炭素鋼の場 合と同じく上述の S45C炭素鋼試験片を用い, 静的圧縮 試験と同一の各温度下で衝撃圧縮試験を行って縦弾性 倸数を求めた。図 $11(\mathrm{a})$ に $45 \mathrm{C}$ 炭素鋼の温度に対する 降伏応力および維弹性係数の温度に対する変化をそれ ぞれムおよびロで示す.さらに, 同図に示した降伏応力

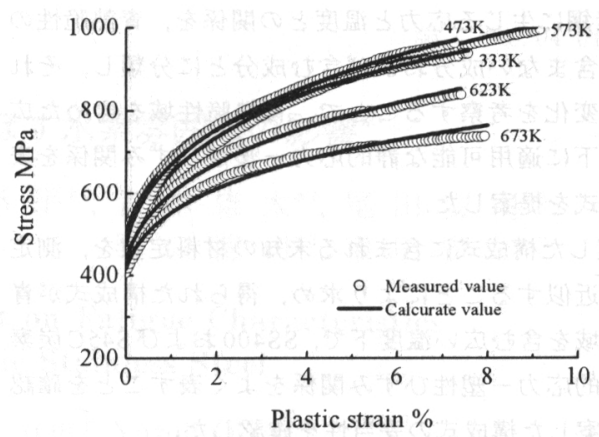

Fig. 12 Static stress - plastic strain curves on S45C

を縦弾性係数で除して得られる降伏ひずみ $\alpha$ の温度に 対する変化を図 $11(\mathrm{~b})$ にで示す. 図11(b)より, SS400 炭素網と同じく, $\alpha$ は温度に対してほぼ線形に変化する ことが確認できる、そこで，293,373,423,523,623 およ び $673 \mathrm{~K}$ における $\alpha$ の测定結果を用い, 線形最小二乗法 で $\alpha_{i}$ を求めた。結果を表 $4(\mathrm{a})$ に, また, 得られた定数 による $\alpha$ の計算結果を図11(b)に直線で示す.

次に, 以上で決定された $\alpha_{i}$ を用いて, 提案する構成 式に含まれる未知の材料定数 $K_{i}, n_{i}, C_{1} \sim C_{3}, T_{0}$ を試 験片に用いた S45C 炭素鋼に関して決定する。すなわ ち, 293,373,423,523,623および $673 \mathrm{~K}$ の各温度下におけ る応力一塑性ひずみ関倸を, 非線形最小二乗法により $\alpha_{i}$ の值を代入した式(6)を用いて近似する.

得られた $\mathrm{S} 45 \mathrm{C}$ 試験片の材料定数 $K_{i}, n_{i}, C_{1} \sim C_{3}, T_{0}$ を表4(b)に, また, 決定された構成式より求めた縦弾性 係数および降伏応力を測定值との比較のために図 11 に

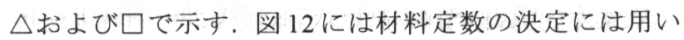
なかった 333，473，573K，さらに，決定にも用いた $623,673 \mathrm{~K} に お け る$ 応力ー塑性ひずみ関係の計算值を測 定值とともに示す，さらに塑性ひずみ $3 \%$ および $5 \%$ に おける温度に対する応力值の変化を同式より求め図 10 中に $\triangle$ で示し, 測定值と比較する. 図12より, 得られ た構成式は各温度下における応力一塑性ひずみ関倸を よく表している. また, 図10より同構成式が, $500 \mathrm{~K}$ 付 近で生じる青熱脆性の影響をよく表している.

すなわち, 提案する構成式は, 青熱脆性域を含む広い 温度域にわたり, SS400のみならずS45C炭素鋼の静的 な変形挙動を表す式として用いることができる。

\section{5. 結 言}

本論文で得られた結果を以下に要約する.

(1)高温下において SS400およびS45C 炭素鋼を試験片 とした静的圧縮試験を行い, 種々の温度下におけるこ れらの材料の応力一塑性ひずみ関係を得るとともに, いずれの材料においても, その変形挙動に青熱脆性の 影響が現れることを確認した。 
(2)炭素鋼に生じる応力と温度との関倸を，青熱脆性の 影響を含まない成分および含む成分とに分類し，それ ぞれの変化を考察することで，青熱脆性域を含めた広 い温度下に適用可能な静的応力ー塑性ひずみ関係を表 す構成式を提案した。

(3)提案した構成式に含まれる未知の材料定数を，測定 結果を近似することにより求め, 得られた構成式が青 熱脆性域を含む広い温度下で，SS400およびS45C炭素 鋼の静的応力ー塑性ひずみ関倸をよく表すことを確認 し，提案した構成式の妥当性を確認した。

\section{文 献}

(1)谷村黄治・三村耕司・楳田努，広ひずみ速度域を対 象とした各種材料グループに適用し得る実用構成式, 材料, 50-3, (2001), 210-216.

(2)例えば林卓夫・田中吉之助, 衝撃工学, (1988), 6470 , 日刊工業新聞社.

(3)S. Tanimura, A practical constitutive equation covering a wide range of strain rates, Int.J.Eng.Sci, 17-9, (1979), 9971004.
(4)U.S.Lindholm, Springer-Verlag, Mechanical Behavior of Materials under Dynamic Loads, (1968), 77-95.

(5)立矢宏・駒形雄一・放生明廣・茶谷明義, 温度およ びひずみ速度依存性を考虑した炭素鋼の動的構成式の 決定，機論，69-681，A(2003), 916-923.

(6)日本塑性加工学会, 高エネルギー速度加工, (1993), 19-25, コロナ社.

(7)例えば大森正信, 吉永芳豊, 武井英雄, 軟鋼の引張 性質におよぼす変形速度の影響，日本金属学会誌，2911, (1965), 1087-1093.

(8)大森正信，材料性質と環境（その2)，日本機械学会 誌, 76-653,(1973), 555-566.

(9)宮川大海・坂木庸晃, 金属学概論, (1998), 136-137, 朝倉書店.

(10)例えば立矢宏・中井智之・放生明廣・茶谷明義，弹 塑性波伝ぱ解析を利用した情報量規準に基づく動的構 成式の決定, 機論, 69-681, A(2003), 916-923.

(11)中川徹・小柳義夫, 最小二乗法による実験データ解 析, (1982), 95-124, 東京大学出版会. 